\title{
Extensive Reading: A Multifaceted Panacea for EFL Students at KKU
}

\author{
Ahmad I. Assiri ${ }^{1} \&$ Ahlullah Siddiqui ${ }^{1}$ \\ ${ }^{1}$ Faculty of Languages and Translation, King Khalid University, Abha, KSA \\ Correspondence: Ahlullah Siddiqui, Faculty of Languages and Translation, King Khalid University, Abha, KSA.
}

Received: June 20, 2021

Accepted: July 22, 2021

Online Published: July 27, 2021

doi: 10.5539/elt.v14n8p40

URL: https://doi.org/10.5539/elt.v14n8p40

\begin{abstract}
This research aims to assess the importance of Extensive Reading (ER) in developing reading comprehension, vocabulary development, and speaking fluency among English as a Foreign Language (EFL) students at King Khalid University (KKU). Most EFL students appear to be under pressure and confront anxiety while acquiring English language competency in basic language skills. According to MacIntyre and Gardner (1994, p. 284), language anxiety is the "feeling of tension and apprehension" with language learning, including listening, speaking, and language comprehension. One thought of making language learning an enjoyable activity is to make language acquisition a natural process instead of a forced and external one. According to Day \& Bamford (2002), the goal of ER is to help students become fluent, independent, and confident readers. ER encourages L2 learners to explore the English language independently, especially in an EFL environment. ER inherently encourages language acquisition by allowing students to read extensively in a relaxed and natural environment, thus developing the basic nuances of the language effortlessly. This approach is also referred as uninterrupted sustained silent reading (USSR). Two distinct groups of students, namely experimental and control groups, will participate in this study. The results will help measure the effect of ER on students' reading comprehension, vocabulary development and speaking fluency. The experimental group will practice effortless ER for almost 12 weeks. Students' performance in the assigned reading task, vocabulary development, and speaking proficiency will be analyzed using SPSS. Finally, the researchers will suggest efficient measures to implement ER as a teaching methodology at the English department, and will also encourage implementation of an ER club at the faculty of languages and translation, KKU.
\end{abstract}

Keywords: anxiety, EFL, extensive reading, speaking fluency, USSR

\section{Introduction}

When students read extensively, they read easy, enjoyable books to build their reading speed and reading fluency. Thus, the aim of Extensive Reading (ER) - also known as graded reading or sustained silent reading- is to help students become better at the skill of reading rather than 'study reading' being directed to language study. When students read extensively, they should read quickly and fluently; at least 150-200 words per minute or a little lower (for beginning students), and the reading content must be accessible. In his study on ER, Hu Hsueh-chao (2000) suggests that having too much unknown vocabulary on a single page would slow the eye's natural movement and affect comprehension. It would turn fluent reading into a form of study reading. A similar study on ER by Nation (1977) suggests that language enables students to read more materials of their choice. According to Al-Homoud \& Schmitt (2009) (among others), ER helps build vocabulary. Beginner-level students at the department of English at KKU read a lot under the guidance of their instructors. In doing so, they come across thousands of words and patterns most of the time, which allow students to develop their vocabulary and grammar. However, it is usually a forced activity as they read only for exams or quizzes. The current study deliberates on devising a methodology where students read effortlessly to develop their comprehension, vocabulary, and fluency. Language learned through unintended pressure or anxiety makes the learning process a fun experience. ER is one such way and means through which EFL students at KKU can overcome the many hindrances they come across while learning English. It was argued that ER enables students to improve reading speed and reading fluency (e.g., Beglar et al., 2012; Tanaka \& Stapleton, 2007), thus allowing for better language processing and efficient use of memory. A study by Grabe (2000) argues that ER builds confidence, motivation, enjoyment, and a love of reading, resulting in making students more effective language users. Anxiety is often a great hindrance in language learning, but according to Ro (2013), ER helps lower anyanxieties about language learning the students may have. ER enhances general language competence, extending to skills beyond reading such as writing, speaking, and listening skills 
(see, e.g., Elly, 1991; Hafiz \& Tudor, 1989). ER allows students to read or listen to a lot of English at or about their ability to develop good reading, writing, and listening habits (see, e.g., Hafiz \& Tudor, 1989). ER helps students get a sense of how grammatical patterns work in context (Elly, 1991). Textbooks and other supplementary materials introduce language patterns, but typically, they don't appear often enough in various contexts to facilitate a deep understanding of how the patterns work. ER boosts a positive attitude towards reading in a foreign language (Day \& Rob, 2015).

\subsection{Objectives: The Proposed Study Addresses the Following Points}
a. To assess the impact of ER on reading comprehension proficiency.
b. To boost the positivity of ER on speaking fluency.
c. To assess EFL learners' attitude towards ER.
d. To suggest ways for implementing the ER club at the Faculty of Languages and Translation, KKU.
e. To suggest ways in which EFL instructors can implement ER strategies in their classrooms.

\section{Literature Review}

One of EFL students' primary skills to develop and master is reading ability in academic contexts. One essential way to create such a skill is to expose students to an ample amount of ER According to Suk (2016), ER is an effective method of motivating and developing reading ability among beginner students; here, we can say EFL students at KKU are no exception.

EFL students at KKU often request their instructors about ways and means they need to adapt to enhance their proficiency and competency in the English language. To address this concern, EFL instructors at KKU give great importance to reading fluency in the first language (L1) and second language (L2) in an English classroom setting. Hence, proficiency and fluency have become important areas of concern for EFL instructors, especially Saudi students. Several empirical studies in different countries have suggested that an ER program improves L2 learners' reading rate and comprehension (see, e.g., Asraf \& Ahmad, 2003); however, studies involving Saudi EFL students are scarce (see, e.g., Al-Homoud \& Schmitt, 2009; Al-Nafisah, 2015).

In this research, we focus on the effects of ER on reading comprehension, vocabulary development, and speaking fluency among EFL students at KKU. In his study on ER, Dickinson (1995, p. 168) clearly states that success in individual reading encourages learner autonomy, which leads to "learning success and enhanced motivation". The idea of extensive usage of ER in a language classroom by Mason \& Krashen (1997) gave new inputs to language instructors. They found that most of the once reluctant EFL learners became eager readers due to comprehensible input with increased exposure to L2 through ER. It is imperative to state here that EFL teaching aims to create autonomous learners (i.e., those who show less inhibition and are eager to explore the vast boundaries of the English language through their hard work, constant motivation, and self-disciplined reading texts of their interest). Therefore, this study will examine the effectiveness of ER in developing general proficiency in the English language, vocabulary development, and speaking fluency among students enrolled in the EFL program at KKU.

ER encourages students to read as much as possible, mainly for pleasure. According to Day \& Bamford (2002), ER promotes reading fluency and increases reading speed (p. 138). As students are assigned to read many comprehensive materials, speed reading becomes essential as it facilitates the enjoyment and comprehension of materials. Reading appears to be one of the problematic skills for EFL Saudi students for various reasons; among which is that students are usually less motivated towards self-reading (Assiri, \& Siddiqui, 2020). In this regard, Blevins (2005), Grabe \& Stoller (2002), Samuels (2006) (among others) have attempted to explore several experimental and quasi-experimental studies to examine ER's effectiveness and support ER's use in English as a second language (ESL) and EFL classroom settings. However, the researchers noticed that students focused less on vocabulary development, speaking fluency, and reading comprehension in an EFL environment. Nuttall (1982) expresses the importance of ER by saying "the best technique to improve your knowledge of a foreign language is to go and spend time among its speakers. The next best way is to read extensively in it" (p. 168). Blevins (2005), Grabe \& Stoller (2002), Samuels (2006) (among others) have shown that ER is a practical approach to improving learners' reading fluency. Reading is considered a mother skill that facilitates mastering other underlying skills of the English language. A typical language classroom encourages students to read short texts that include topics related to their interests, fascinating facts, or pictorial representation. The primary aim of an EFL instructor in a reading class is to help the students get an overview of the text, guide them to guess the meaning from the context, and complete the comprehension questions with little or no support. EFL instructors always try to teach self-reading habits to their students by allowing them to choose short stories, books, and related materials. EFL learners enjoy reading the materials, short stories, and textbooks of their choice, and it is always a pleasurable 
experience for them. As a result, they would build up their English language competency, and it would never be a forced exercise. It is interesting to note that the aim and interest of EFL instructors and students run parallel.

Students enrolled at the B.A. in English program at KKU have to read many prescribed materials in English initially, but many students tend to develop fear and hesitate to spend time reading the assigned texts. Therefore most of them devote minimal time for reading. According to Vaezi (2007), a student in an EFL class will probably go through a standard reading comprehension procedure consisting of the three stages: pre-, post-, and during-reading. Here, the EFL instructors try to focus on a language area that students can quickly master. The researchers in this study attempted to develop ER skills in their students, focusing on reading for pleasure and not on intensive reading. Alderson \& Urquhart (1984) stress that reading activity involving completing a task may give students momentary satisfaction. Still, when students read and complete an exercise based on unknown texts, they will develop more confidence levels.

Here, it is important to differentiate between intensive and extensive reading. Most EFL experts do not consider intensive reading as genuine reading, wherein students' primary focus is on completing the task-based activity. On the other hand, when students develop confidence through self-reading and become aware that they don't have to read a lesson that culminates with a task-based activity, they start reading for pleasure and not pressure.

In a typical learning setting, students read a text and do exercises afterward. Most students concentrate on fulfilling the tasks they must do without considering the real purpose of reading: read for pleasure and information. Such an attitude towards reading affects the students' performance. Students' negative attitude towards reading tasks will negatively impact their reading skills, negatively affecting other language learning skills. ER, however, has been shown to have positive impacts on EFL students' reading skills, for it engages students in pleasurable activities. Students lose focus and concentration when completing a comprehension task after reading an unknown text in English. The primary objective of reading in an EFL classroom is to generate the idea of reading by the students and complete the different exercises on comprehension, vocabulary development, summarizing, etc. Beginner level EFL students at the department of English, KKU, are under the impression that reading in English means completing the assigned tasks at the end of the lesson; due to this factor, after few weeks of enthusiasm, they start losing focus in their reading class. To EFL instructors, who are successful in instilling confidence in their students, students are expected to read widely on various topics and make completion of assigned tasks a secondary task. EFL instructors, with the primary objective of helping their students read more and develop an interest in their English reading skills, received very positive feedback from their students and their parents too.

During this short research study, the researchers conveyed to the experimental group that they want them to read texts of their choice through ER techniques. Students can choose texts that may contain at the most five unknown vocabularies on a page. Their primary focus is on enjoying the texts they read and gathering information through self-reading, reading for the sake of reading, with no immediate stress on providing specific comprehension answers to subjective or objective questions. In an ER class, the instructor is a mere facilitator who provides a wide variety of books and supplementary reading materials in English. The instructor may change the reading materials or texts upon the students' request. The researchers noticed the primary reason for the request of new reading texts included complicated texts with a considerable amount of unknown vocabulary, uninteresting titles, and textbooks. On the other hand, texts with the most minimal unfamiliar language, pictorial, and graphical explanation of ideas, along with tags related to them, drew a very positive response to ER. The EFL instructors informed their students that they do not have to complete any cumbersome exercises at the end of the texts; they just needed to have fun reading. It is a recognized fact that ER is usually done by highly literate people most of the time. In this study, the researchers expect their students to achieve sustained development in the competency level in English as that of the highest achievers in their class. Therefore, ER entails that students choose to read books that best interest them. The researchers noticed that EFL students at KKU were very optimistic about the ER approach during the training period. Many students directly shared with their EFL instructors that the best thing about this approach was that they were not under due pressure to find the proper answers to the comprehension questions, usually given at the end of the lesson in intensive reading classes. Students also knew that there was no grade, and the whole exercise went with the students' will. This sort of liberty helps students to pace their reading based on their interest and proficiency level. It leads to form profound self-induced habits, which eventually helps them to attain great academic success. On the other hand, many EFL instructors at KKU shared with the researchers in this study their experience of low motivational levels towards reading among students due to the above factors.

A reading habit, once formed, stays throughout the academic carrier of young college students. The researchers further noticed that most of the students seemed not to be aware of the habit of reading in their free time. According to Krashen (2004), such low reading habits among college students can be expressed as a literary crisis. ER helps to overcome such vital needs in a student's life. Hence, EFL instructor's role becomes ever more significant in 
developing love towards reading habits in their students, especially in their free time. The ER program suggested by the researchers provides the solution to productive reading habits. The reading material is consciously chosen and pertains to students' interests; therefore, they can read more text. As a result, students slowly adapt themselves to self-reading, whereby their confidence level boosts up, and with time they become independent learners of a language. As EFL instructors know that forced learning does not stay for long, ER acts as a primary supplement to students who wish to be independent learners.

The voluntariness of reading is the hallmark of this approach. This makes it pleasurable and pressure-free, encouraging students to read more and more texts appropriate for their level, thus not having to resort to word-by-word translation. This way, students shape their method of reading and become practitioners of ER while enjoying what they do.

\section{Methodology}

This action research used a mixed-method approach. The researchers used a convergent parallel design as both quantitative and qualitative data were collected. The researchers will analyze the obtained data separately and focus on relevant correlations between the information (cf. Mertler, 2019). In this study, students read supplementary reading materials of their interest, easy to understand, containing familiar vocabulary, and content of their liking and the one they found enjoyable. The students who took part performance in pretests and posttests of reading rate and language proficiency helped the researchers to gauge their performance. The researchers administered a t-test to compare students' language proficiency, vocabulary development, and speaking fluency. Results indicate that ER is a practical approach to improve students' reading rate and general language proficiency. ER aims of covering large amounts of reading material enjoyable for students will be analyzed too. The participants were 25 male students at the English department, KKU in Saudi Arabia, who used supplementary materials and took weekly quizzes using Blackboard. The participants took part in a survey to measure their intrinsic motivation after adopting the ER approach. They also took an external exam (i.e., Aptis) to measure their reading comprehension before and after. Each strand of results helped the researchers to analyze the results from both sets of data.

\section{Results and Discussions}

Two different sections of levels 2 and 4 students enrolled in the B.A. program of English at KKU were randomly selected to participate in this study as a control group and experimental group. The English department conducts an entrance exam for students aspiring to enroll in the B.A. program at the faculty of languages and translation. Therefore, the proficiency level of students at levels 2 and 4 is assumed to be similar. The researchers also conducted a proficiency test for all the students participating in this study to ascertain their level of proficiency. The researchers noticed no statistically significant mean difference between the scores attained by students of the control group and those achieved by the experimental group before participating in this study. The mean score of the control group in the reading proficiency comprehension task was 21.2. The experimental group got 23.5 out of the total grade of 40, indicating that their level of English proficiency is almost similar. The test group got a list of supplementary reading materials to choose from each week based on their interest and ease of reading. The reading materials used for the ER training for the experimental group consisted of the 'Tapestry Series for Arab students' by Oxford, a variety of fiction, non-fiction, adventure, travelogue materials downloaded from the internet, sports magazines, newspapers, etc. The researchers made it clear to the experimental group that they have to finish the reading task at their convenience, and there is no penalty for late completion of the reading task; instead, it was up to the participants to decide on the time slot they prefer to read. The participants had to keep a record to themselves of how much time each one of them spends on each reading material. Once they finish, they can inform their instructor and borrow the next reading material. The instructors divided the experimental group of students into sub-groups based on their interests. They were encouraged to share their experience and observations of the reading materials used in the specified group. The instructor met the experimental group of students twice a week to share their expertise experience reading materials. The researchers presented them with specific techniques on how to read fast while retaining the vocabulary in context; the researchers even encouraged the students to show their progress in reading, involvement of peers in sharing knowledge, any difficulty they came across, etc. This training continued for 12 weeks. The table below indicates the performance of the control and experimental groups in the reading comprehension assessment tasks. 
Table 1. Reading Comprehension Mean Result

\begin{tabular}{lllllllll}
\hline $\begin{array}{l}\text { Reading } \\
\text { Comprehension }\end{array}$ & Mean & $\begin{array}{l}\text { Std. } \\
\text { Deviation }\end{array}$ & Skewness & $\begin{array}{l}\text { Std. Error of } \\
\text { Skewness }\end{array}$ & Range & Minimum & Maximum & Sum \\
\hline Test Group & 84.58 & 11.127 & -1.171 & .524 & 39 & 60 & 99 & 1607 \\
Control Group & 64.53 & 17.995 & -.512 & .524 & 60 & 30 & 90 & 1226 \\
\hline
\end{tabular}

The above results show a statistically significant mean difference between the achievement of students of the experimental group and that of the control group in the posttest in reading comprehension, speaking fluency, and vocabulary development. Students in the control group got 64.53 (out of 100) in the reading comprehension posttest, while the mean score of the students in the experimental group was 84.58. The results express that students who participated in the ER training sessions exhibited a greater understanding of the texts than those in the control group.

Table 2. Speaking performance of both the groups

\begin{tabular}{lllllllll}
\hline $\begin{array}{l}\text { Speaking } \\
\text { Performance }\end{array}$ & Mean & $\begin{array}{l}\text { Std. } \\
\text { Deviation }\end{array}$ & Skewness & $\begin{array}{l}\text { Std. Error of } \\
\text { Skewness }\end{array}$ & Range & Minimum & Maximum & Sum \\
\hline Test Group & 79.74 & 12.714 & -.444 & .524 & 44 & 55 & 99 & 1515 \\
Control Group & 66.474 & 12.2173 & -.141 & .524 & 42.0 & 44.0 & 86.0 & 1263 \\
\hline
\end{tabular}

The above table indicates the obtained mean score of the experimental group in the speaking fluency assessment stood at 79.94 (out of 100), whereas that of the control group stood at 66.47. Thus, the mean score in the speaking fluency assessment indicates a significant improvement in students who participated in the ER training program.

Table 3. Vocabulary development means of both groups

\begin{tabular}{lllllllll}
\hline $\begin{array}{l}\text { Vocabulary } \\
\text { Development }\end{array}$ & Mean & $\begin{array}{l}\text { Std. } \\
\text { Deviation }\end{array}$ & Skewness & $\begin{array}{l}\text { Std. Error of } \\
\text { Skewness }\end{array}$ & Range & Minimum & Maximum & Sum \\
\hline Test Group & 82.33 & 14.45 & -.1 .07 & .524 & 45 & 58 & 97 & 1580 \\
Control Group & 65.5 & 18.8 & -.511 & .524 & 56 & 46 & 88 & 1296 \\
\hline
\end{tabular}

As far as the vocabulary development variable is concerned, the students' mean score in the experimental group stood at 82.33 . The control group stood at 65.5 , thus signifying good achievement. Therefore, the overall results indicate that students who received training in ER have shown remarkable improvement in students' performance in all three variables: reading comprehension, speaking fluency, and vocabulary development.

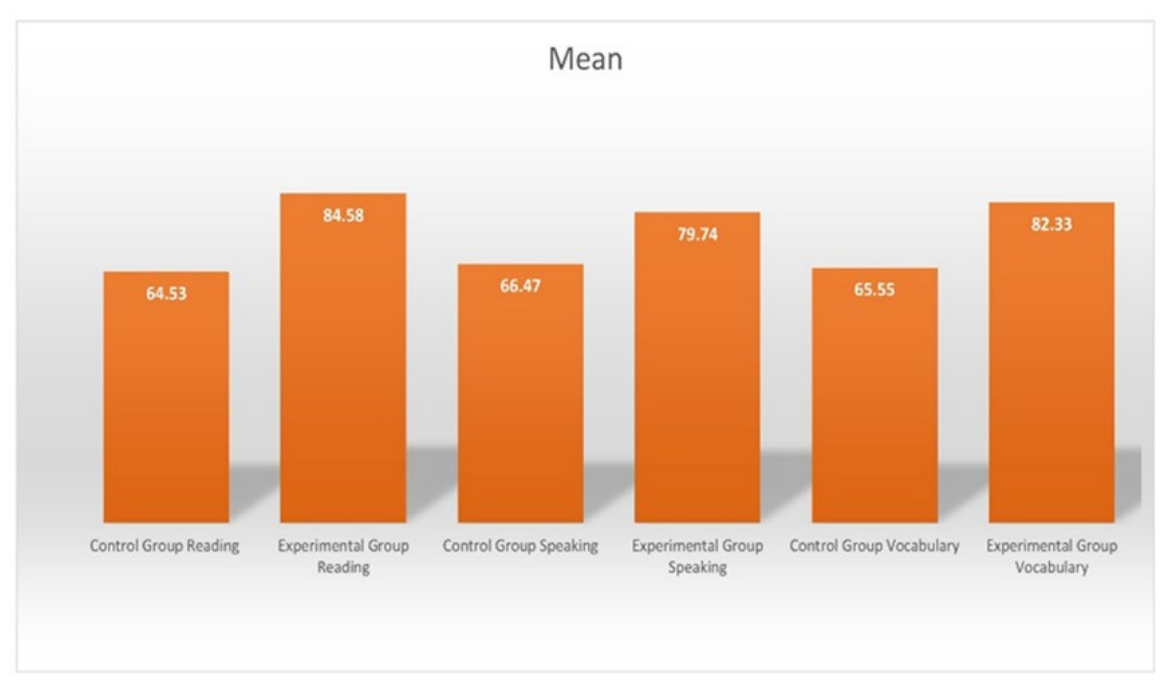

Figure 1. Comprehensive results of both the groups

The above comprehensive performance graph indicates that the supplementary reading materials of student's interest and choice-other than prescribed textbooks-have played a significant role in motivating the students to read more at their self-pace. As a result, they were ultimately able to improve reading comprehension, speaking fluency, and vocabulary development.

The researchers observed that the experimental group even exchanged their reading materials with their peers, sharing enthusiasm and incredible knowledge acquired after reading the said materials. The instructors took regular feedback from the students about their progress. They gave practical suggestions sharing more extensive 
ideas on the recently completed topics to reconnect their ideas with the real world. Students in the experimental group immensely rated the idea that ER has also helped them improve their writing and grammar. About $66 \%$ of the students in the experimental group expressed their opinion that the ER training program has allowed them to improve all the basic skills of the English language. For instance, they have indicated that reading in English is fun. The same students have expressed that they are eager and more interested in reading more supplementary materials in English, apart from their course books.

As for the type of reading material students like to read, between $33 \% \& 44 \%$ have shown interest and motivation in reading horror and ghost stories, fiction, mystery, and adventurous topics. Around $77 \%$ of the students in the experimental group have shown a high level of satisfaction with the class practice of taking short feedback and exchanging ideas once they finished the reading materials of their interest. The researchers observed that the respective instructors gave ER training sessions informally to better monitor the area of interestof separate genres of each student and oversee their progress. The researchers felt that helpful feedback on the number of reading material students covered, length of the content in the form of new texts they studied, and ways in which the experimental group can extend their ideas with the practical world gave new inputs and even maximized their experience of self-reading without restrictions, relieving them of undue pressure of completing a designed task assigned to them.

This study suggests that encouraging ER practices in the English class, especially for the students in the skill courses at Saudi universities in general (and KKU in particular) will positively impact their performance in the undergraduate English program. Therefore, establishing an ER club, which will provide various books, magazines, travelogues, newspapers, etc., to all students in the English department, will be favorable. There would be a digital assessment mechanism where students could conveniently register free of cost for periodic assessment under the supervision of an instructor. The instructor will also maintain a periodic record of students'progress in the system for assessment. The researchers suggested providing opportunities to EFL students to interact with their peers at other Saudi universities through the English club will help them immensely, thus expanding the ER culture. The researchers concluded that the ER approach impacts many areas of student learning, such as comprehension, speaking fluency, and vocabulary development. Therefore, the researchers recommend that educators and administrators should take serious steps towards adopting ER in reading classes.

\section{Conclusion, Limitations and Future Research}

This short study on ER emphasizes reading more and more texts of students' interests. ER is essential for the overall development of the language learning skills for EFL (as well as for ESL). Notably, it has shown that ER has a multifaceted impact on language learning. The experimental group who underwent 12 weeks training program showed remarkable progress in their reading comprehension, speaking fluency, and vocabulary development. This study strongly recommends establishing an ER club in the English department at KKU and other Saudi universities as well. It is an acknowledged fact that stress-free language learning encourages studentsto be actively involved in ER and leads to completing the tasks they have at hand with confidence and a high level of satisfaction, which is the study's primary aim. The study also recommends that instructors at the EFL program at KKU provide the opportunity to their respective students to go for ER at least twice a week, either as an ungraded assignment or reading for fun through some interactive exercises. This study was conducted on a small sample size of level two and four male students only at KKU. The same can be replicated with female students and a large study can be conducted on EFL students at other Saudi public universities to verify the importance of ER. The researchers believe that an extended period of ER training to EFL students will help to show larger insights on the effectiveness of this approach.

\section{Acknowledgment}

The authors extend their appreciation to the Deanship of scientific research at King Khalid University for funding this study (Project no. 290) and the first study titled: "Interpretive Reading as a Strategy to Construct Meaning in EFL Reading Comprehension: A Case Study at King Khalid University" was published in AWEJ volume 11, Number 2, June 2020.

\section{References}

Alderson, J. (1984). Reading in a foreign language: A reading problem or a language problem? In C. Alderson \& A. H. Urquhart (Eds.), Reading in a foreign language (pp. 1-25). London: Longman.

Al-Homoud, F., \& Schmitt, N. (2009). Extensive reading in a challenging environment: A comparison of extensive and intensive reading approaches in Saudi Arabia. Language Teaching Research, 13, 383-401. https://doi.org/10.1177/1362168809341508 
Al-Nafisah, K. I. (2015). Effectiveness of the Extensive Reading Program in Developing Saudi EFL University Students' Reading Comprehension. Arab World English Journal, 6(2), 98-109. https://doi.org/10.24093/awej/vol6no2.8

Asraf, R. M., \& Ahmad, I. S. (2003). Promoting English Language Development and Reading Habit among Students in urban Schools through the Guided Extensive Reading Program. Reading in a Foreign Language, $15(2)$.

Assiri, A. I., \& Siddiqui, A. (2020). Interpretive reading as a technique to Construct meaning in an EFL Reading Comprehension: A Case Study at King Khalid University. Arab World English Journal, 11(2), 395-410. https://doi.org/10.24093/awej/vol11no2.28

Beglar, D., Hunt, A., \& Kite, Y. (2012). The effect of pleasure reading on Japanese university EFL learners' reading rates. Language Learning, 62, 665-703. https://doi.org/10.1111/j.1467-9922.2011.00651.x

Blevins, W. (2005). The effectiveness of reading fluency and the English language learner. The Language Teacher, 29, 13-16.

Day, R. R., \& Bamford, J. (2002). Top ten principles for teaching extensive reading. Reading in a Foreign Language, 14, 136-141.

Dickinson, L. (1995). Autonomy and motivation: A literature review. System, 23(2), 165-174. https://doi.org/10.1016/0346-251X(95)00005-5

Grabe, W., \& Stoller, F. L. (2002). Teaching and Researching Reading. New York: Pearson Education. https://doi.org/10.4324/9781315833743

Horwitz. (1988). The beliefs and myths of language learning of beginning university foreign language students. Modern language journal, 73(3), 283-294. https://doi.org/10.1111/j.1540-4781.1988.tb04190.x

Iwahori, Y. (2008). Developing Reading Fluency: A Study of intensive and Extensive Reading in EFL. Reading in a Foreign and Second Language, 20(1), 70-91. Retrieved from https://files.eric.ed.gov/fulltext/EJ791535.pdf

Krashen, S. (2004). The power of reading: Insights from the research (2nd ed.). Libraries Unlimited, Westport, Connecticut.

MacIntfe, P. D., \& Gardner. (1994). Language anxiety: Its relation to other anxieties and processing in native and second languages. Language Learning, 41, 513-534. https://doi.org/10.1111/j.1467-1770.1991.tb00691.x

Mason, B., \& Krashen, S. (1997). The Extensive reading in English as a foreign language program. The System, 25(1), 91-102. https://doi.org/10.1016/S0346-251X(96)00063-2

Mertler, C. A. (2019). Introduction to educational research (2nd ed.). Thousand Oaks, CA: SAGE.

Nuttall, C. (1982). Teaching Reading Skills in a Foreign Language. Oxford: Heinemann.

Ro, E. (2013). A case study of extensive reading with an unmotivated L2 reader. Reading in a Foreign Language, $25,212-233$.

Samuels, S. J. (2006). Reading fluency: Its past, present, and future. In T. V. Rasinski, C. Blachowicz \& K. Lems (Eds.), Fluency instruction: Research-based best practices (pp. i7-20). New York: The GuilfordPress.

Suk, N. (2016). Teacher and student perceptions of extensive reading activities. Modern English Education, 17(1), 69-88.

Tanaka, H., \& Stapleton, P. (2007). Increasing reading input in Japanese high school EFL classrooms: An empirical study exploring the efficacy of extensive reading. The Reading Matrix, 7(1), 115-131.

Taylor, S. E. (2006). Fluency in silent and loud reading. Retrieved from https://www.readingplus.com/schools/pdfs/FluencyInSilentReading.pdf

Vaezi, S. (2007). Theories of Reading. Retrieved from https://www.teachingenglish.org.uk/articles/theories/-reading

\section{Copyrights}

Copyright for this article is retained by the author(s), with first publication rights granted to the journal.

This is an open-access article distributed under the terms and conditions of the Creative Commons Attribution license (http://creativecommons.org/licenses/by/4.0/). 